\title{
THE INESSIVE CASE OF LITHUANIAN 'LONG' (DETERMINATE) ADJECTIVES AND THE PHONETIC REALISATION OF THE ACUTE INTONATION IN PROTO-BALTIC
}

The purpose of the paper is to find an historical explanation for the inessive case-forms of determinate, or 'long' adjectives of Standrad Lithuanian. It argues that Standard Lithuanian iness.sg. fem. gerõjoje, masc. gerãjame etc. do not descend from their 'fuller' Old Lithuanian counterparts but rather reflect an independent formation. This independent formation is best understood as directly reflecting the inherited, ProtoBalto-Slavonic and/or Proto-Indo-European locative case, secondarily enlarged by the inessive clitic Proto-East-Baltic *=ến. The discussion of the phonological developments presupposed by this reconstruction yields interesting results concerning the phonetic realisation of the acute intonation in Proto-Baltic times.

Keywords: historical morphology, Baltic, Lithuanian, adjective, inessive case, locative case, prosody, acute intonation.

Е. Гиль (Кельнский университет, Германия)

\section{Инессив литовских членных прилагательных и фонетическая реализация акутовой интонации в прабалтийском}

Статья посвящена происхождению падежных форм инессива членных прилагательных в современном литовском языке. Высказывается гипотеза о происхождении этих литовских падежных форм не от более полных форм инессива, засвидетельствованных в старолитовских текстах, но непосредственно из прабалтославянского, и тем самым праиндоевропейского, локатива. Обсуждение фонологической стороны этой гипотезы приводит к выводам относительно фонетической реализации акутовой интонации в прабалтийском.

Ключевые слова: историческая морфология, балтийские языки, литовский язык, имя прилагательное, падеж инессив, падеж локатив, просодия, акутовая интонация.

As is well known, from an historical perspective the case-forms of Lithuanian 'long' adjectives are composites which originally contained two clearly separable elements (cf. most recently Hock 2016, Sommer 2016/2017, 2018, Gelumbeckaite 2020). The first element is, in each case, the relevant form of the indeterminate, or 'short' 
adjective. The second element is the corresponding case-form of a clitic identical in origin with the pronoun Lith $j i s, j i ̀$ 'he, she'.

This is most clearly shown by those case-forms of Lithuanian 'long' adjectives whose endings contain circumflex long vowels and diphthongs. Cf. (1) for a representative selection of such case-forms in the inflection of the adjective geras 'good'.

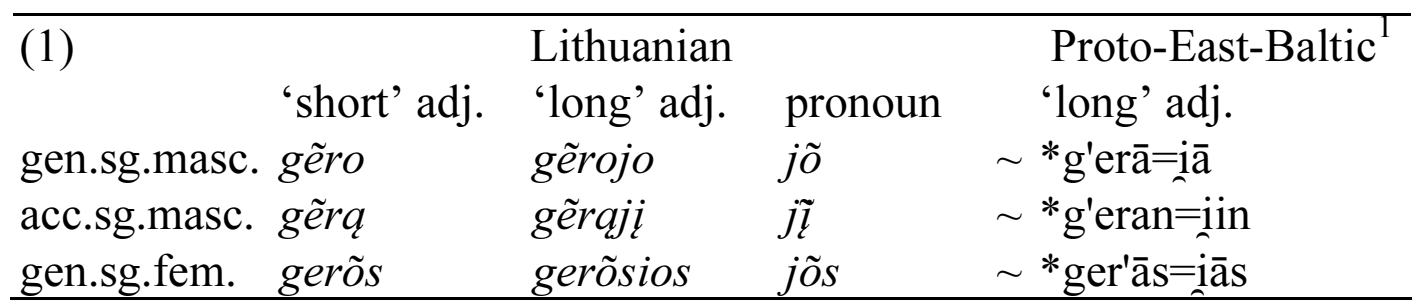

The same principle is obviously valid for those case-forms of Lithuanian 'long' adjectives which originally contained endings with acute long-vowels. This becomes obvious as soon as the socalled Leskien's Law is taken into account. According to this wellestablished sound law, acute long vowels have been secondarily shortened in the last syllable of a Standard Lithuanian word-form. In the inflection of Standard Lithuanian adjectives, this shortening affected the 'short' adjective and the second element of the 'long' adjective. By contrast, the first element of the 'long' adjective, originally identical with the corresponding case-form of the 'short' adjective, remains unaffected by Leskien's shortening, which evidently operated only after the univerbation of both elements had been completed. This is shown in (2).

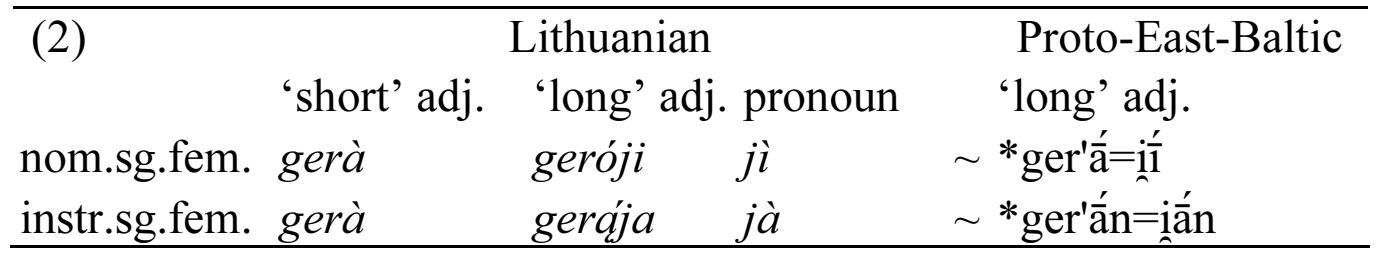

Finally, the same can be demonstrated also for case-forms containing acute diphthongs in their endings. Here one has to take into account the well-established fact that acute diphthongs have been shortened by Leskien's Law only in polysyllabic words. In

\footnotetext{
${ }^{1}$ Here and in the following, in all pre-Lithuanian, Proto-East-Baltic, and Proto-Baltic reconstructions the acute intonation on long vowels and diphthongs is marked by ' over the acute long vowel or the first component of an acute diphthong. Long vowels and diphthongs bearing the circumflex intonation receive no special diacritic mark. The place of word-stress is marked by ' preceding the stressed vowel or diphthong.
} 
monosyllables they are not shortened but undergo metatony, i.e. switch from the acute to the circumflex intonation (cf. Stang 1966: 116, 126, Pronk 2012: 235-238, Hock 2016: 376-380, Hill et al. 2019: 161-162). Accordingly, in such case-forms as given in (3) Leskien's shortening affected the 'short' adjectives and the second element of their 'long' counterparts. The first element of the 'long' adjectives, protected from the shortening by the clitic, remained entirely unaffected. In the pronoun, etymologically acute diphthongs remained unaffected by Leskien's shortening but received the circumflex intonation.

\begin{tabular}{|c|c|c|c|c|c|}
\hline (3) & & Lithuanian & & & Proto-East-Baltic \\
\hline & 'short' adj. & 'long' adj. & pronoun & & 'long' adj. \\
\hline instr.sg.masc. & gerù & gerúoju & juõ & $\sim$ & ${ }^{*} \operatorname{ger}^{\prime} \overline{\mathrm{O}}=\mathrm{i} \mathbf{i} \overline{\mathrm{o}}$ \\
\hline acc.pl.masc. & gerùs & gerúosius & juõs & $\sim$ & ${ }^{*}$ ger'ós $=\mathrm{i}$ iôs \\
\hline nom.pl.masc. & geri & geríeji & jie & $\sim$ & * ger'ệ $=\mathrm{ié}$ \\
\hline
\end{tabular}

However, in dialects of Lithuanian, including the contemporary standard language, the inflectional paradigm of 'long' adjectives contains several case-forms which are strikingly deviating from the above stated principle. This is most clearly shown by the inessive case which is given in (4a) following such grammars and handbooks as Ulvydas et al. (1965: 477-505), Senn (1966: 142-168), and Ambrazas et al. (1997: 134-158). For the time prior to the wellknown pre-Lithuanian word-stress retraction from non-acute syllables on following acute syllables (so-called Saussure's Law), the inessive case-forms given in (4a) presuppose more ancient forms reconstructed in (4b). If one compares the reconstructions given in (4b) with those in (4c), where the above stated principle has been mechanically applied, the difference between the forms implied by Standard Lithuanian and those required by the theoretical expectation becomes obvious. Both Proto-East-Balt iness.sg. fem. *ger'ā=iāiến, masc. *ger'a=iamến and iness.pl. fem. *ger'ās=iāaến, masc. *ger'ōs=iōosén are one syllable shorter than the theoretically expected forms. The missing syllable is obviously the last syllable of the corresponding 'short' adjective in the inessive case, i.e. ProtoEast-Balt sg. fem. *ger'āiến, masc. *ger'amến and pl. fem. *ger'āsến, masc. * ger'ōsến. If this syllable were present also in the 'long' innessive case-forms, their Standard Lithuanian outcome would be not the actually existing sg. fem. gerõjoje, gerãjame and pl. fem. gerõsiose, masc. geruõsiuose, as given in (4a), but rather sg. fem. †gerojẹ́joje, masc. †geramẹjame and pl. fem. †gerosẹjose, masc. †geruoséjuose. 


\begin{tabular}{|c|c|c|c|c|}
\hline \multicolumn{3}{|c|}{$(4)$} & 'short' adj. & 'long' adj. \\
\hline \multirow[t]{4}{*}{$\mathrm{a}$} & iness.sg.fem. & Lith & gerojè & gerõjoje \\
\hline & iness.sg.masc. & & geramè & gerãjame \\
\hline & iness.pl.fem. & & gerosè & gerõsiose \\
\hline & iness.pl.masc. & & geruosè & geruõsiuose \\
\hline \multirow[t]{4}{*}{$\mathrm{b}$} & iness.sg.fem. & PEBalt & *ger'āiến & *ger'ā=iāiến \\
\hline & iness.sg.masc. & & *ger'amé́n & * ger'a=iamến \\
\hline & iness.pl.fem. & & *ger'āsến & *ger'ās=iāầén \\
\hline & iness.pl.masc. & & *ger'ōsến & *ger'ōs=iōsến \\
\hline \multirow[t]{4}{*}{$\mathrm{c}$} & iness.sg.fem. & PEBalt & $=$ & †ger'āiến=iāiến \\
\hline & iness.sg.masc. & & $=$ & †ger'amến=iamến \\
\hline & iness.pl.fem. & & $=$ & †ger'āsến=iāsến \\
\hline & iness.pl.masc. & & $=$ & †ger'ōsến=iōōsến \\
\hline
\end{tabular}

The traditional explanation of this strange situation starts with the observation that case-forms predicted by theory and just constructed above did once exist in Lithuanian. Such inessive forms are recurrent in Old Lithuanian texts from late $16^{\text {th }}$ and $17^{\text {th }} \mathrm{c}$., especially in Dasukša's Postill dating from 1599 (cf. Zinkevičius 1957). Accordingly, the contemporary Standard Lithuanian shorter inessive case-forms of 'long' adjectives are explained as having developed out of such Old Lithuanian fuller forms by some kind of secondary shortening or haplology (cf. Stang 1966: 271; Zinkevičius 1981: 37; 1996: 123-124; Hock 2016: 380; Gelumbeckaitè 2020: $53-54)^{2}$. This hypothetical development is given in (5).

\begin{tabular}{lllll}
\hline (5) & & Old Lith & Standard Lith \\
& iness.sg. & fem. & gerojé $=$ joje & $>$ gerõjoje \\
& masc. & geramé $=$ jame $>$ gerãjame \\
& insess.pl. & fem. & gerosé $=$ jose & $>$ gerõsiose \\
& masc. & geruosé $=$ juose $>$ geruõsiuose \\
\hline
\end{tabular}

This traditional explanation is unsatisfactory for the following two reasons. First, it is entirely ad hoc. Apart from the inflection of 'long' adjectives, such a development is not attested anywhere else in the Lithuanian grammar or lexicon. Second, the traditional explanation is too unspecific because it does not explain why the shortening would eliminate a whole syllable (-ję-, -mé-) in the singular but not in the plural where just the vowel (-é-) is lost.

\footnotetext{
${ }^{2}$ Similarly Sommer (2018: 160-163) where an interplay of phonological and purely morphological factors is suspected. This account is particularly difficult to assess until it has been spelt out in detail.
} 
In the present paper an alternative account will be suggested which explains the Standard Lithuanian inessive case of 'long' adjectives in a less arbitrary and formally more straightforward manner. The starting point of this new account is the fact that the shorter inessive case-forms of Standard Lithuanian 'long' adjectives do not necessarily descend from their fuller Old Lithuanian counterparts. In fact, both variant forms of the inessive, i.e. fem. gerojéjoje and gerõjoje etc., actually coexisted in Old Lithuanian times and may be, therefore, equally old ${ }^{3}$. At least in theory, the two different sets of inessive case-forms in the inflection of the Lithuanian 'long' adjectives can have emerged independently from each other.

This becomes a possible and even plausible assumption as soon as one considers the origin of both categories involved, the inessive case and the 'long' adjectives. As is well known, the inessive case of Lithuanian is a recent innovation which has no counterpart in the closely related West Baltic (i.e. Old Prussian), or Slavonic. The nouns, pronouns, and 'short' adjectives demonstrate that the inessive reflects the inherited locative secondarily univerbated with a clitic Proto-East-Baltic *=ến (cf. now Villanueva Svensson 2020: 12-13, $32-38)^{4}$. A part of the relevant data is given in (6). Note that the shape of the Lithuanian o-stem inessive singular betrays the recent age of this univerbation which must have postdated the regular monophthongisation of Proto-Baltic *ai to Proto-East-Baltic *ẹ..

\footnotetext{
${ }^{3}$ Unfortunately, no inessive forms of 'long' adjectives seem to occur in several of the most ancient Old Lithuanian texts, the Catechisms by Mažvydas (1547) and Vilentas (1579), or the Wolfenbüttel Postill (15731574). See respectively Stang (1929: 125-128), Ford (1969: 84-85), and Gelumbeckaitè (2020).

${ }^{4}$ The Proto-Baltic ending of the $\mathrm{eh}_{2}$-stem loc.sg. should bear the acute intonation. However, the lack of Saussure's Law in the iness.sg. of Lithuanian root-stressed nouns (rañkoje etc.) and its operation in the iness.sg. of Lithuanian mobile nouns (dienojè etc.) most clearly point to pre-Lithuanian iness.sg. *-āi=ến. This presupposes Proto-Baltic loc.sg. *-āi, not *-ấi. At the same time, a group of adverbs ending in Lith -ì (ankstì 'early' etc.) are best explained as fossilised reflexes of $\mathrm{eh}_{2}$-stem loc.sg. in Proto-Baltic *-ắi (cf. Villanueva Svensson 2016). The situation remains unclear. The equally unexpected circumflex in the iness.pl. (Lith rañkose, dienosè etc.) seems to point to a metatony (i.e. a change from acute to circumflex) in the whole inessive. The issue was recently discussed in Bolotov \& Oslon (2019: 84-87) and Villanueva Svensson (2020: 34-38).
} 


\begin{tabular}{|c|c|c|c|c|c|c|c|}
\hline (6) & PIE & & OCS & & PBalt & PEBalt & Lith \\
\hline & loc.sg. & & loc.sg. & & loc.sg. & iness.sg. & iness.sg. \\
\hline o-stem nouns & *-oi & $>$ & $-\check{e}$ & $\sim$ & $*$-ai & $\rightarrow *$-ẹe=én $\quad>$ & $-e$ \\
\hline eh ${ }_{2}$-stem nouns & $*-\hat{h}_{2} \mathrm{i}$ & $>$ & $-\check{e}$ & $\sim$ & *-āi & $\rightarrow *$-āi $\mathrm{i}=\overline{\mathrm{e}} \mathrm{n} \quad>$ & -oje \\
\hline deictic pronouns masc. & *-omi & $>$ & -omb & $\sim$ & *-âmi & $\rightarrow *$-ami $=\overline{\mathrm{e} n}>$ & -ame \\
\hline
\end{tabular}

In contrast, the Lithuanian 'long' adjective inflection must be much older. Being found in a similar shape also in West Baltic (i.e. Old Prussian), and in Slavonic (cf. again Sommer 2016/2017: 221247 ; 2018), the 'long' adjective inflection appears to be, in essence, an innovation dating to Proto-Balto-Slavonic times.

This means that the Lithuanian inessive of 'long' adjectives has to be explained as a new case-form, emerging by way of univerbation of the inherited locative with Proto-East-Baltic *=ến in a system which already contained the 'long', i.e. doubly inflected case-forms of adjectives. It seems clear that under these conditions the new inessive case of doubly inflected 'long' adjectives could be constructed in two different ways.

The first strategy would build the new inessive case-forms by means of combining the 'ready for use' inessive of the 'short' adjective with the 'ready for use' inessive of the (clitic) pronoun, both elements being already enlarged by Proto-East-Baltic *=én. As shown in (7) this strategy would immediately produce a part of the Old Lithuanian fuller variant forms such as the iness.sg. fem. gerojé $=$ joje etc. The pattern would then have been followed by all other forms already in pre-Lithuanian times (i.e. prior to the most recent Leskien's Law).

(7)

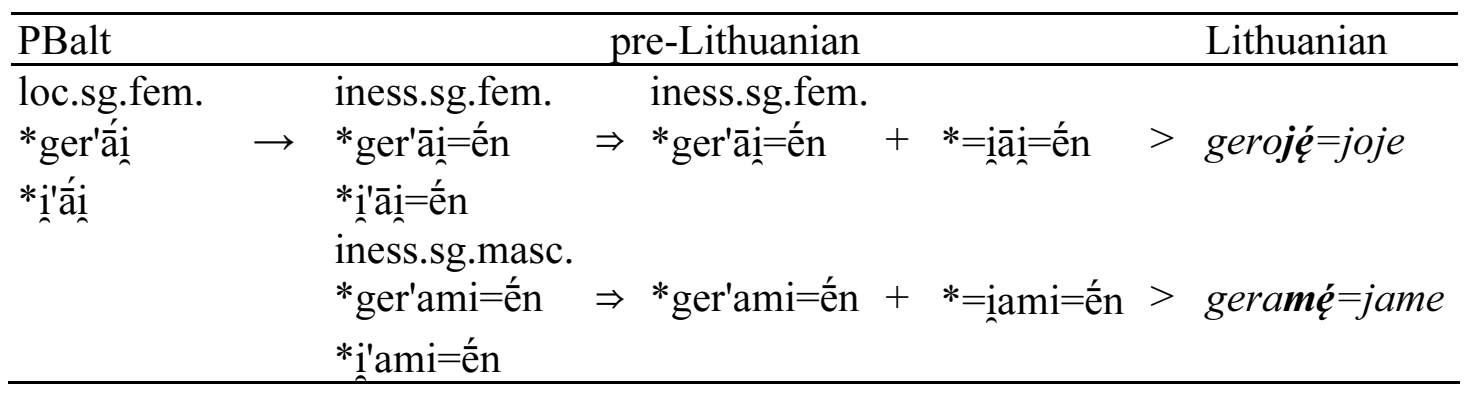

The second strategy would simply enlarge the inherited 'ready for use' locative case-form of the 'long' adjective with Proto-EastBaltic *=én. This process would generate variant forms of the inessive containig a reflex of Proto-East-Baltic *=ến just once, as the last element in the chain of three. As shown in (8), from a purely morphological perspective this would straightforwardly generate the 
shorter variant forms of the inessive in Lithuanian 'long' adjectives such as sg. fem. gerõjoje etc.

\begin{tabular}{|c|c|c|c|c|c|}
\hline (8) & PBalt & & PEBalt & & Lithuanian \\
\hline $\mathrm{a}$ & loc.sg.fem. & & iness.sg.fem. & & \\
\hline \multirow{6}{*}{$\mathrm{b}$} & *ger'āi=iāāi & $\rightarrow$ & 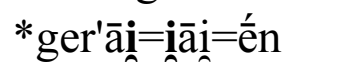 & $>$ & gerõjoje \\
\hline & loc.sg.masc. & & iness.sg.masc. & & \\
\hline & *ger'ai=iami & $\rightarrow$ & *ger'ai=iami=ến & $>$ & gerãjame \\
\hline & loc.pl.fem. & & iness.pl.fem. & & \\
\hline & $\begin{array}{l}\text { *ger'āsu=iāsu } \\
\text { loc.pl.masc. }\end{array}$ & $\rightarrow$ & $\begin{array}{l}\text { *ger'āsi=iāsu=én }^{\text {iness.pl.masc. }} \\
\text { ines. }\end{array}$ & $>$ & gerõsiose \\
\hline & ${ }^{*}$ ger'ōsu=iōosu & $\rightarrow$ & *ger'ōsi $=\mathbf{i}$ iōsu=ến & $>$ & geruõsiuose \\
\hline
\end{tabular}

The only point which remains to be clarified are the phonological developments to be assumed at the juncture between the first element of such constructions (i.e. the 'short' adjectives) and their second element (i.e. the pronominal clitic). Here just two sound changes have to be postulated:

- Proto-Balt *ViiV $>$ Lith $V j V$ in the singular,

- Proto-Balt $*$ CuiV $>$ Proto-East-Balt $* \mathrm{CiiV}>$ Lith $\mathrm{CiV}$ (i.e. palatalised $C$ ) in the plural.

The second sound change is potentially confirmed for Lithuanian by a clear parallel in a different domain of grammar. As shown in Hill (2012: 19-24), the development of PIE *ui into *ii and its subsequent simplification into palatalising $*_{i}$ when followed by a long vowel is the easiest way to explain several feminine caseforms of East-Baltic u-adjectives (cf. 9 for Lith gilùs 'deep').

\begin{tabular}{|c|c|c|c|c|c|}
\hline (9) & PIE & & PBalt & & Lith \\
\hline & $\begin{array}{l}\text { gen.sg.fem. } \\
*_{\text {-u-ieh }} \text {-es } \\
\text { dat.sg.fem. }\end{array}$ & $>$ & *-i-iāas & $>$ & giliõs \\
\hline & $\begin{array}{l}{ }_{\text {-u-ieh }} \text {-ei } \\
\text { nom.pl.fem. }\end{array}$ & $>$ & $*_{\text {-i-i }}$ iāi & $>$ & gìliai \\
\hline & ${ }^{*}$-u-ieh ${ }_{2}$-es & $>$ & $*_{\text {-i-i }}$ ās & $>$ & gilios \\
\hline
\end{tabular}

In contrast, the first sound change cannot be independently confirmed by reference to evidence somewhere else in the morphology or in the lexicon. However, it can be shown that this sound change does not violate the rules of East Baltic historical phonology. 
Such a violation may be suspected in the dative case of Lithuanian 'long' adjectives where the fem. gẽrajai and masc. gerájam (phonologically /-aijai/ and /-'aijam/) seem to presuppose retention of the old $*_{i}$ before the pronominal clitic. However, as shown in (10), both forms are recent creations, based on the corresponding 'short' case-forms fem. gẽrai and gerám. Accordingly, gẽrajai is spelt <géraijei> in Klein's first printed grammar of Lithuanian, where gerájam is still <geramjam> (Klein 1654: 20, 27, cf. 1653: 35, 49). The same is true for Kurschat (1876: 246-249), where the feminine form is given as $<$ gẽraijai $>$ and in the masculine gender $<$ gerámjam $>$ coexists with $<$ gerájām $>$. The regularity of the recent assimilation of $m$ by $j$ is confirmed by 'long' adjective dat.du. fem. gerójom, masc. geríejiem (cf. <gerémjem> in Klein 1654: 20).

\begin{tabular}{llll}
\hline (10) & Lithuanian & & \\
\hline & 'short' adj. & prn. & \\
a & $\begin{array}{l}\text { dat.sg.fem. } \\
\text { gẽrai }\end{array}$ & $>$ jái & gẽrajai \\
b & $\begin{array}{l}\text { dat.sg.masc. } \\
\text { gerám }\end{array}$ & & \\
c & $\begin{array}{l}\text { dat.du.fem. } \\
\text { geróm } \\
\text { dat.du.masc. } \\
\text { geríem }\end{array}+$ jóm $(=d v i e m)$ & $>$ gerójom \\
& + jím $(=d v i e m)$ & $>$ geriejiem \\
\hline
\end{tabular}

A much more serious vialotation of the change asumed in (8a), i.e. Proto-Balt $* \mathrm{ViiV}>$ Lith $V j V$, is observed in the masculine form of the nominative plural and in the feminine form of the nominativeaccusative dual of 'long' adjectives. As shown in (11), these two case-forms clearly presuppose a preservation of Proto-Balt $* \mathrm{ViiV}$ until the time of monophthonisation of Proto-Balt *ai into ProtoEast-Balt *ẹ. The preservation of the dipththong in the nom.pl. masc. and nom.-acc.pl. fem. * g'erái=iái (> Lith gerieji) in (11) is in sharp contrast with its simplification in the loc.sg. masc. *ger'ai=iami (> Lith gerãjame) in (8a).

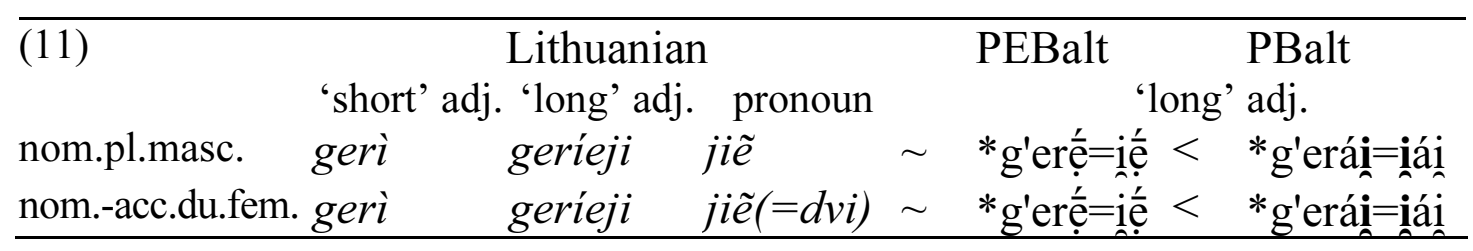


However, this conflict between the case forms correlates with the difference in the intonation of the diphthong in question. In the loc.sg. masc. Proto-Balt *ger'ai=iami the diphthong was spoken with the circumplex intonation. In the nom.pl. masc. and nom.-acc.pl. fem. Proto-Balt *g'erái=iái the diphthong had the acute. For this reason, the preservation of the diphthong in the latter case-forms does not necessarily constitute counter-evidence against its regular simplification in the former.

In theory, the contrast between Proto-Balt $*$-ai $=$ iami $>$ ProtoEast-Balt $*_{-\mathbf{a}}=$ iami and Proto-Balt $*_{-}$ái $=$iáa $>$Proto-East-Balt $*-\hat{e}=1$ ié might even provide information concerning the phonetic realisation of the acute intonation in Proto-Baltic times. If in Proto-Baltic the acute intonation was realised by means of glottalisation (like partly in Latvian and Žemaitian dialects of Lithuianian) ${ }^{5}$, it can be assumed that the glottal stricture actually followed the long vowel or diphthong in question. This means that Proto-Balt *g'erái=iái reconstructed in (11) was phonetically realised as something close to * [g'erai'iai ']. It seems natural to assume that in such a structure, where two relevant Proto-Balt $*_{i}$ were separated by $*^{*}\left[{ }^{2}\right]$, the simplification of the geminate was less likely than in the loc.sg. masc. *[ger'aiiami] and fem. *[ger'āiiāi] reconstructed in (8a).

The discussion has shown that the shorter innesive case-forms of the Standard Lithuanian 'long' adjectives (such as iness.sg. fem. gerõjoje etc.) do not descend from their fuller Old Lithuanian counterparts but are best explained as directly reflecting the corresponding inflectional forms of the inherited locative case.

\section{Bibliography}

Ambrazas, Vytautas, Emma Geniušienè, Aleksas Girdenis, Nijole Sližienė, Dalija Tekorienè, Adelẻ Valeckienè \& Elena Valiulytė. 1997: Lithuanian Grammar. Vilnius: Baltos lankos.

Bolotov, S. G., M. V. Oslon. 2019: "Pravilo Leskina-OtrembskogoSmočin'skogo" i mnimye izključenija iz zakona de Sossjura. BaltoSlavjanskie Issledovanija 20. 55-91.

Ford, Gordon B. Jr. 1969: The Old Lithuanian Catechism of Baltramiejus Vilentas (1579). A phonological, morphological, and syntactical investigation. The Hague/Paris: Mouton.

Gelumbeckaitè, Jolanta. 2020: Pronominierte Nominalformen in der Wolfenbütteler Postille (1573-1574). Baltistica 55(1). 49-82.

Hill, Eugen. 2012: Die Entwicklung von $*^{\mathrm{u}}$ vor unsilbischem $*_{\mathrm{i}}$ in den indogermanischen Sprachen Europas: Die Stammsuppletion bei u-

${ }^{5}$ Cf. most recently Jasanoff (2017: 70-103) with extensive references. 
Adjektiven und das Präsens von 'sein'. North-Western European Language Evolution 64/65. 5-36.

Hill, Eugen, Daniel Kölligan, Corinna Scheungraber \& Michael Frotscher. 2019: The development of prefixation in time and space. Ditropic clitics and prosodic realignment in dialects of Indo-European. Transactions of the Philological Society 117(2). 157-198.

Hock, Wolfgang. 2016: Pronominierte Nominalformen im Altlitauischen. Indogermanische Forschungen 121, 365-386.

Jasanoff, Jay H. 2017: The Prehistory of the Balto-Slavic Accent. Leiden: Brill.

Klein, Daniel. 1653: Grammatica Litvanica. Regiomonti: Reusner. (Unveränderter Nachdruck mit einem Vorwort von Harald Haarmann. Hamburg: Buske, 1977).

Klein, Daniel. 1654: Compendium Lituanico-Germanicum, Oder Kurtze und gantz deutliche Anführung zur Littauischen Sprache. Königsberg: Reusner. (Unveränderter Nachdruck mit einem Vorwort von Harald Haarmann. Hamburg: Buske, 1977).

Kurschat, Friedrich. 1876: Grammatik der littauischen Sprache. Halle: Verlag der Buchhandlung des Waisenhauses.

Pronk, Tijmen. 2012: Proto-Indo-European long vowels and Balto-Slavic accentuation. Baltistica 47(2), 205-247.

Senn, Alfred. 1966: Handbuch der litauischen Sprache. Bd. I: Grammatik. Heidelberg: Winter.

Sommer, Florian. 2016/2017 [2019]: Diachronie und areale Effekte. Zur Entstehung der bestimmten Adjektive im Baltischen und Slavischen. Die Sprache 52 (2), 202-255.

Sommer, Florian. 2018: The historical morphology of definiteness in Baltic. Indo-European Linguistics 6(1), 152-200.

Stang, Chr[istian] S. 1929: Die Sprache des litauischen Katechismus von Mažvydas. Oslo: Dybwad.

Stang, Chr[istian] S. 1966: Vergleichende Grammatik der baltischen Sprachen. Oslo: Universitetsforlaget.

Ulvydas, K., A. Laigonaitè, V. Mažiulis, V. Urbutis, V. Vaitkevičiūtė \& A. Valeckienè. 1965: Lietuviu kalbos gramatika. I tomas. Fonetika ir morfologija (daiktavardis, büdvardis, skatvardis, juvardis). Vilnius: Mintis.

Villanueva Svensson, Miguel. 2016: Lithuanian ankstì, artì, tolì and Baltic and Slavic Auslautgesetze. Scando-Slavica 62(2), 160-182.

Villanueva Svensson, Miguel. 2020: Balto-Slavic accentology, Auslautgesetze, and the Baltic secondary local cases. Baltistica 55(1), 5-42.

Zinkevičius, Z[igmas]. 1957: Lietuviu kalbos j̇vardžiuotiniu būdvardžiu istorijos bruožai. Vilnius: Valstybinè politinès ir mokslinès literatūros leidykla.

Zinkevičius, Z[igmas]. 1981: Lietuviu kalbos istoriné gramatika. II. Ivardžiai. Büdvardžiai. Skaitvardžiai. Veiksmažodžiai. Nekaitomosios kalbos dalys. Istorinès sintaksès apybraiža. Vilnius: Mokslas.

Zinkevičius, Zigmas. 1996: The history of the Lithuanian language. Vilnius: Mokslo ir enciklopedijų leidykla. 